\title{
Physiological Effects of Nondialyzable Melanoidin in Rats
}

\author{
Hisanao Takeuchi, Yasuji NishioKa, Miki Fujishiro \\ and Keiichiro Muramatsu \\ Department of Agricultural Chemistry, Faculty of Agriculture, Shizuoka University, \\ 836 Ohya, Shizuoka-shi 422, Japan \\ Received July 8, 1986
}

\begin{abstract}
The absorption and excretion of melanoidins, a mixture of the low- and high-molecular weight components (LMM and HMM), and the LMM component prepared from a L-lysine-D-glucose system, at $\mathrm{pH} 7.4$ and 9.0, respectively, and the effects of these melanoidins on cholesterol metabolism were examined in rats. Weanling male rats of the Wistar strain weighing about $50 \mathrm{~g}$ were fed diets containing $10 \%$ casein (10C) with $3 \%$ of a melanoidin or $25 \%$ casein $(25 \mathrm{C}$ ) with $4 \%$ of the melanoidin for 12 weeks, and the $25 \mathrm{C}$ diet including $3 \%$ of the melanoidin or LMM for 8 weeks. The growth and organ weights of the melanoidin-supplied groups were not different from those of the control ones. In rats given the melanoidin diets with both protein levels, the kidneys became dark brownish due to the accumulation of the melanoidin, though the accumulated amount was extremely small (nearly $0.5 \mathrm{mg} / \mathrm{g}$ wet kidney), and gel filtration chromatography of a water extract of the kidneys on Sephadex G-75 showed that the deposited melanoidin was the LMM component. Most of the ingested melanoidin, however, was excreted in the feces, and on comparison of the gel chromatographic patterns, the melanoidin groups were found to have more fecal LMM than the control ones. When rats were provided with LMM, HMM increased in their feces. The addition of melanoidin suppressed the level of plasma total cholesterol and elevated the fecal excretion of total lipids and total cholesterol. The urinary contents of protein and total creatinine did not differ from those in the control groups.
\end{abstract}

Fahey et al. ${ }^{1)}$ showed that brownish pigments, separated from cane molasses, stimulated the growth of rats. Lee et al. ${ }^{2)}$ reported that growth was depressed and diarrhea ensued in rats fed diets containing Maillard reaction products formed in a reaction mixture of reducing sugar and protein or amino acid. The high-molecular weight part of nondialyzable melanoidin is hardly digested or absorbed, and long-term feeding of it did not affect the growth of rats. ${ }^{3,4)}$ The low-molecular weight component of the melanoidin had a depressing effect on protein digestion and $a b-$ sorption. ${ }^{57)}$ However, the growth response and the digestibilities of protein and lipids in rats given dietary melanoidin were not significantly different from those in animals fed a control diet. ${ }^{8)}$ When a diet containing a carbohydrate-egg albumin reaction compound was supplied to rats for a year, enlargement of the hearts and kidneys was observed. ${ }^{9}$ Measure- ment of excreted melanoidin on the basis of the ${ }^{15} \mathrm{~N}$-balance in rats fed nondialyzable ${ }^{15} \mathrm{~N}$-melanoidin prepared from a model system of glucose and ${ }^{15} \mathrm{~N}$-glycine revealed that $76 \%$ of the dietary melanoidin was excreted in the feces. ${ }^{8)}$

The present study was performed to examine the absorption and excretion of melanoidins, a mixture of the low- and high-molecular weight components (LMM and HMM), and the LMM component, which were prepared from a L-lysine-D-glucose system at $\mathrm{pH} 7.4$ and 9.0, respectively, and the effects of these melanoidins on the total cholesterol concentrations in the plasma, liver and feces.

\section{MATERIALS AND METHODS}

Preparation of nondialyzable melanoidin. Melanoidin was prepared by the following method with reference to 


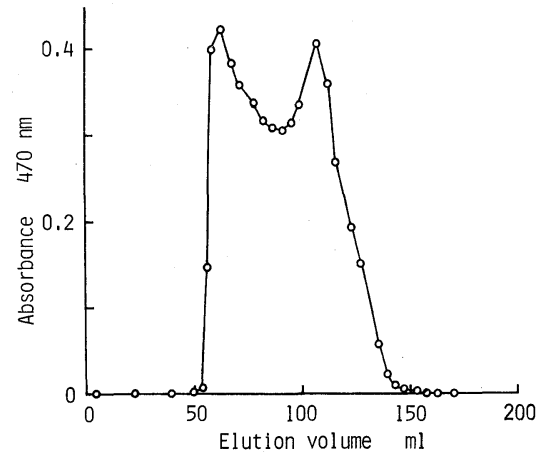

FIG. 1. Gel Filtration Chromatography of the Prepared Melanoidin on Sephadex G-75 $(1.5 \times 78 \mathrm{~cm})$.

the previous reports. ${ }^{8,10 \sim 12)}$ An aqueous solution ( $\mathrm{pH} 7.4$ ) consisting of $0.6 \mathrm{M}$ D-glucose monohydrate (Takeda Chemical Industries Co., Ltd., Osaka), 0.9 M L-lysine monohydrochloride (Ajinomoto Co., Ltd., Tokyo) and $0.75 \mathrm{M}$ sodium bicarbonate was reflux-boiled at $100^{\circ} \mathrm{C}$ for $30 \mathrm{hr}$. The resulting muddy solution ( $\mathrm{pH} \mathrm{6.6)}$ was dialyzed in cellulose tubing against running water for 5 days, and then the dialyzate was lyophilized to yield a light brownish powder. The nitrogen, free glucose and lysine contents of the prepared melanoidin were $10.84,0.29$ and $0.15 \%$, respectively, as determined by the Kjeldahl method and an enzymatic method (Glucose B-test; Wako Pure Chemical Industries, Ltd., Osaka), and with an amino acid analyzer (type 835; Hitachi, Ltd., Tokyo). The gel filtration pattern of this melanoidin is shown in Fig. 1. Low-molecular weight melanoidin (LMM) was prepared by modification of the reaction conditions reported previously ${ }^{13)}$ as follows. A reaction mixture $(\mathrm{pH} 9.0)$ containing $0.6 \mathrm{M} \mathrm{D}$ glucose, $0.9 \mathrm{M}$ L-lysine monohydrochloride and $1.2 \mathrm{M}$ sodium bicarbonate was refluxed with heating at $100^{\circ} \mathrm{C}$ for $1 \mathrm{hr}$. The following preparation process was performed as described above. The $\mathrm{pH}$ of the final solution was 7.95 and the nitrogen level of the final product was $9.53 \%$, as determined by the Kjeldahl method. The residues of glucose and lysine in the dialyzed solution were similar to those in the case of the prepared melanoidin mentioned above. The gel filtration chromatography pattern of the resulting LMM is presented in Fig. 2.

Animals and diets. Male rats of the Wistar strain (Shizuoka Laboratory Animal Center, Hamamatsu), weighing about $50 \mathrm{~g}$ and fed a stock diet $(25 \%$ casein) for 4 to 5 days post-weanling, were divided into seven groups of 4 rats each and provided with test diets containing $10 \%$ casein with or without $3 \%$ melanoidin, and $25 \%$ casein with or without $4 \%$ melanoidin $(10 \mathrm{C}, 10 \mathrm{C} 3 \mathrm{M}, 25 \mathrm{C}$ and $25 \mathrm{C} 4 \mathrm{M}$ ) for 12 weeks (Exp. I), and $25 \%$ casein diets supplemented with nothing, $3 \% \mathrm{LMM}$ or $3 \%$ melanoidin (25C, $25 \mathrm{C} 3 \mathrm{~m}$ and $25 \mathrm{C} 3 \mathrm{M}$ ) for 8 weeks (Exp. II). The compositions of the diets are shown in Table I. The

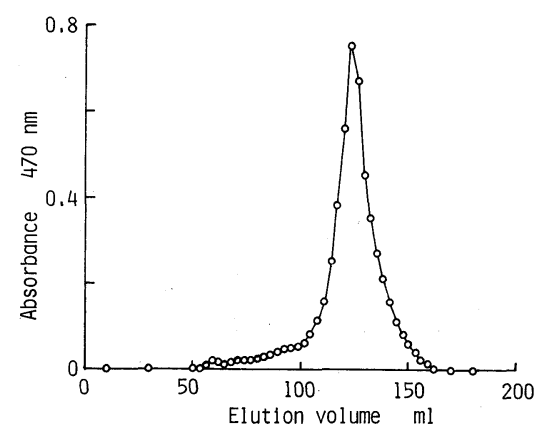

Fig. 2. Gel Filtration Chromatography of the Prepared Low-molecular Weight Melanoidin on Sephadex G-75 $(1.5 \times 78 \mathrm{~cm})$.

supplemented levels of melanoidin and LMM were chosen on the basis of the results of a pre-experiment in which the addition of both compounds at more than $3 \%$ in the $10 \%$ casein diet and more than $4 \%$ in the $25 \%$ casein diet caused diarrhea in the rats. The animals were individually housed in suspended wire cages in a room maintained at $24 \pm 1{ }^{\circ} \mathrm{C}$ and with about $50 \%$ relative humidity, with illumination from $6: 00$ to $18: 00$, and they accepted freely the diets and water. The excreted feces and urine of the rats were separately collected in melabolic cages for the last three days before sacrifice. After the animals had been were deprived of food for $12 \mathrm{hr}$, they were killed by decapitation and then the blood was immediately collected in heparinized polyethylene tubes. Several organs were removed after perfusion. All samples were frozen at $-20^{\circ} \mathrm{C}$ untill analyzed.

Gel filtration chromatography on Sephadex $G$ and determination of melanoidin. Melanoidin, LMM, and lyophilized and powdered feces were dissolved in distilled water, followed by centrifugation at $2,500 \mathrm{rpm}$ for $20 \mathrm{~min}$. The kidneys were homogenized in three parts of water for one min, followed by deproteinization by the addition of sulfosalicylic acid solution to this homogenate to a final concentration of $3 \%$. and then centrifugation at 12,000 rpm for $20 \mathrm{~min}$. The supernatant was subjected to column chromatography on Sephadex G-75 (Pharmacia Fine Chemicals, Sweden) successively with distilled water, at a flow rate of $15 \mathrm{ml}$ per $\mathrm{hr}$. The brown pigment was colorimetrically quantitated on the basis of the optical density at $470 \mathrm{~nm}$, using the original melanoidin as a standard.

Determination of total cholesterol in plasma, liver and feces. The plasma total cholesterol concentration was determined by a modification of the method of ZakHenly. ${ }^{14)}$ The liver and feces were powdered after lyophilization. Powdered liver was extracted with ten portions of a chloroform-methanol mixture $(2: 1, \mathrm{v} / \mathrm{v})^{15)}$ and overlapping $0.9 \%$ sodium chloride. Total lipids and total choles- 
TABlE I. COMPositions OF DiETs ${ }^{a}$

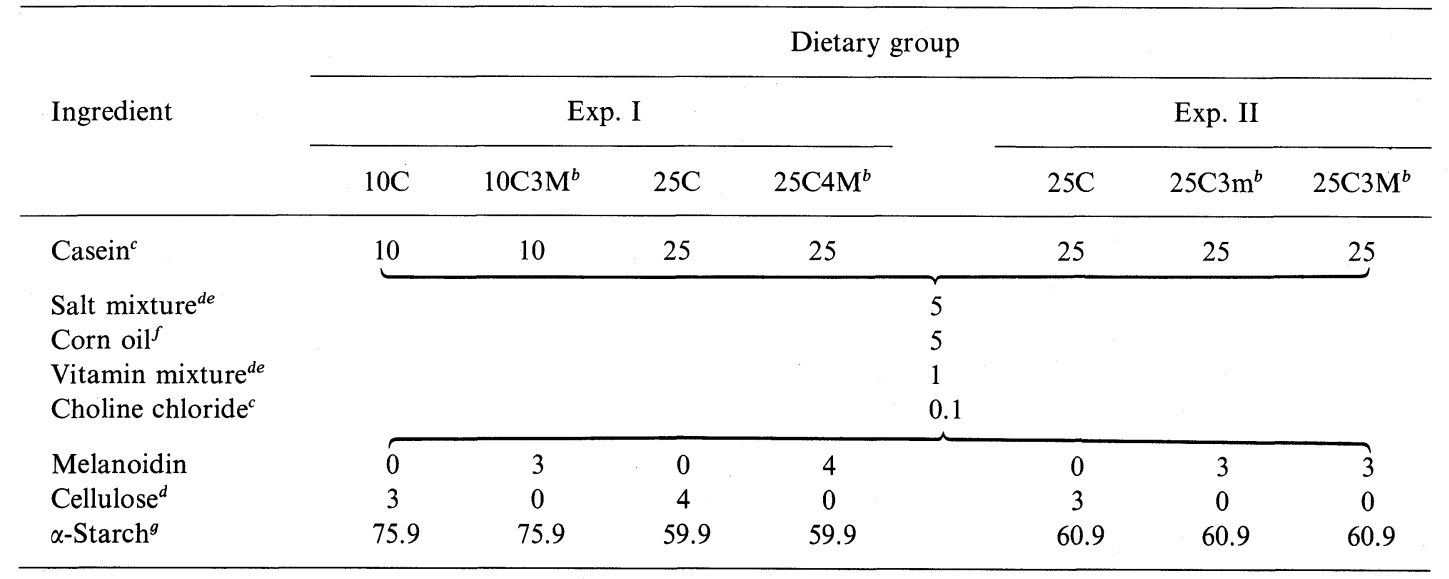

a Chocola A which contains vitamin A, 30,000 IU, and vitamin D, 3,000 IU per ml, and $\alpha$-tocopherol (Eizai Co., Ltd., Tokyo) were added at 0.07 and $0.1 \mathrm{ml}$ per $100 \mathrm{~g}$ diet, respectively.

$b$ The mixture of the low- and high-molecular weight melanoidin components (M), and the low-molecular weight component $(\mathrm{m})$ were prepared as described in the text.

c Nakarai Chemicals, Ltd. (Kyoto).

d Oriental Yeast, Ltd. (Tokyo).

e A. E. Harper, J. Nutr., 68, 405 (1959).

$f$ Honenseiyu Co., Ltd. (Tokyo).

$g$ Asahi-kagakukogyo Co., Ltd. (Wakayama).

terol in the chloroform layer were estimated by the methods of Bragdon ${ }^{16)}$ and Zak-Henly, ${ }^{14)}$ respectively, after evaporation of the solvent. Dried feces was heated with a chloroform-methanol mixture $(1: 1, \mathrm{v} / \mathrm{v})$ in a capped test tube at $70 \pm 0.5^{\circ} \mathrm{C}$ for $24 \mathrm{hr}$, according to a slight modification of the method reported by Van Beresteyn et al. ${ }^{17)}$ One part of the extract was used for the determination of total lipids ${ }^{15)}$ and cholesterol ${ }^{14)}$ after the solvent had been evaporated. The dry residue after evaporation of the other portion of the extract was dissolved in $70 \%$ methanol, to which one drop of acetic acid per $20 \mathrm{ml}$ had been added, and then the same volume of petroleum ether $(40 / 60)$ as of the methanol solution was added, followed by stirring. The petroleum ether layer was used to estimate the total cholesterol content of the feces according to the method of Zak-Henly. ${ }^{14)}$ The methanol layer was used for the deteremination of fecal total bile acids by the enzymatic method described by Van Beresteyn et al. ${ }^{17)}$

Other analyses. The amount of total creatinine in the plasma and feces was estimated according to the previous report. ${ }^{18)}$ The urinary protein content was determined by Lowry's method. ${ }^{19)}$

\section{RESULTS}

The dietary groups with either protein level in Exp. I showed similar body weight gains, food intakes and several organ weights with the exception of that of the brain (Table II). There were also no differences among these parameters in the groups in Exp. II (Table III). These results were basically in agreement with those of previously reported experiments. $4,8,20)$

The amount of total cholesterol in the plasma of rats fed the $10 \mathrm{C} 3 \mathrm{M}$ and $25 \mathrm{C} 4 \mathrm{M}$ diets (melanoidin groups) was decreased compared with that in animals supplied with the $10 \mathrm{C}$ and $25 \mathrm{C}$ diets (control groups), as in the study of Gomyo and Miura. ${ }^{20)}$ The fecal total cholesterol content in the melanoidin-fed groups was higher than that in the control groups, which was different from the results of Gomyo and Miura. ${ }^{20)}$ Rats given the test diets in both experiments had similar levels of liver total cholesterol (Tables II and III). As shown in Tables II and III, the amounts of total lipids in the liver of the dietary groups did not differ significantly in each experiment, but the addition of the melanoidin and the lowmolecular weight component (LMM) to the control diets resulted in the fecal excretion of a higher amount of total lipids than in the case 
Table II. Body Weight Gains, Food Intakes, Organ Weights, and Total Cholesterol and Total Lipids in the Plasma, Liver and Feces of Rats Fed the Test Diets FOR 12 WEEKS (Exp. I)

\begin{tabular}{|c|c|c|c|c|c|c|}
\hline \multirow[b]{2}{*}{ Analyzed item } & & & \multicolumn{4}{|c|}{ Dietary group } \\
\hline & & & $\begin{array}{l}10 \% \text { Casein } \\
(10 \mathrm{C})\end{array}$ & $\begin{array}{c}10 \mathrm{C}+3 \% \\
\text { melanoidin }^{a}\end{array}$ & $\begin{array}{c}25 \% \text { Casein } \\
(25 \mathrm{C})\end{array}$ & \multirow{2}{*}{$\begin{array}{c}\begin{array}{c}25 \mathrm{C}+4 \% \\
\text { melanoidin }^{a}\end{array} \\
277.6 \pm 6.0\end{array}$} \\
\hline Body weight & gain & $\mathrm{g} / 12$ weeks & $202.9 \pm 8.8^{b}$ & $195.0 \pm 8.7$ & $256.4 \pm 8.4$ & \\
\hline Food intake & $\mathrm{g} / 12$ & weeks & $1148.5 \pm 23.9$ & $1151.2 \pm 38.9$ & $1140.7 \pm 30.6$ & $1170.3 \pm 9.6$ \\
\hline \multicolumn{3}{|c|}{ Organ weight liver } & $3.33 \pm 0.10$ & $3.32 \pm 0.03$ & $3.56 \pm 0.16$ & $3.85 \pm 0.14$ \\
\hline & \multirow{3}{*}{\multicolumn{2}{|c|}{$\begin{array}{l}\text { kidney } \mathrm{g} / 100 \mathrm{~g} \\
\text { brain } \\
\text { lung body wt. }\end{array}$}} & $0.67 \pm 0.01$ & $0.70 \pm 0.01$ & $0.74 \pm 0.03$ & $0.76 \pm 0.01$ \\
\hline & & & $0.64 \pm 0.01$ & $0.59 \pm 0.01$ & $0.51 \pm 0.02 *$ & $0.49 \pm 0.01^{*}$ \\
\hline & & & $0.38 \pm 0.01$ & $0.39 \pm 0.01$ & $0.35 \pm 0.01$ & $0.35 \pm 0.01$ \\
\hline & heart & & $0.29 \pm 0.01$ & $0.29 \pm 0.01$ & $0.29 \pm 0.01$ & $0.27 \pm 0.01$ \\
\hline \multirow{3}{*}{$\begin{array}{l}\text { Total } \\
\text { cholesterol }\end{array}$} & plasma & $\mathrm{mg} / 100 \mathrm{ml}$ & $53.8 \pm 5.0$ & $35.6 \pm 2.8^{*}$ & $75.6 \pm 4.0$ & $55.4 \pm 5.5^{*}$ \\
\hline & liver & $\mathrm{mg} / \mathrm{g}$ dry & $14.3 \pm 0.8$ & $15.3 \pm 1.5$ & $15.1 \pm 0.5$ & $14.8 \pm 1.0$ \\
\hline & feces & $\begin{array}{l}\mathrm{mg} / 100 \mathrm{~g} \\
\text { body wt./ } \\
\text { day }\end{array}$ & $3.0 \pm 0.4$ & $5.9 \pm 0.6^{*}$ & $1.4 \pm 0.2$ & $2.7 \pm 0.3^{*}$ \\
\hline \multirow[t]{2}{*}{$\begin{array}{l}\text { Total } \\
\text { lipids }{ }^{c}\end{array}$} & liver & $\begin{array}{l}\text { mg palmitic } \\
\text { acid/g dry }\end{array}$ & $143.5 \pm 5.4$ & $163.7 \pm 13.8$ & $155.3 \pm 10.1$ & $154.4 \pm 7.5$ \\
\hline & feces & $\begin{array}{l}\text { mg palmitic } \\
\text { acid } / 100 \mathrm{~g} \\
\text { body wt./day }\end{array}$ & $40.3 \pm 3.3$ & $122.9 \pm 6.3^{*}$ & $45.3 \pm 2.5$ & $87.1 \pm 8.2^{*}$ \\
\hline
\end{tabular}

a A mixture of low- and high-molecular weight melanoidin components.

$b \quad$ Mean \pm SE. * Significantly different from that in the $10 \mathrm{C}$ or $25 \mathrm{C}$ group at $p<0.05$, with the Student $t$-test.

c Total lipids are expressed as the amount of palmitic acid.

of the control rats. The total bile acids excreted in the feces of the melanoidin- or LMMprovided rats increased as compared with in the control groups, though the concentration was low [the amounts (means $\pm \mathrm{SE}$ ) of fecal total bile acids expressed as mg lithocholic acid $/ 100 \mathrm{~g}$ body wt./day in the $25 \mathrm{C}, 25 \mathrm{C} 3 \mathrm{~m}$ and $25 \mathrm{C} 3 \mathrm{M}$ rats were $0.4 \pm 0.1,1.1 \pm 0.3$ and $0.9 \pm 0.3$, respectively].

A photograph of the kidneys in which melanoidin accumulated is presented in Fig. 3 . Gel chromatography of a water soluble extract of the kidneys on Sephadex G-75 revealed that the ingested melanoidin was stored in the kidney of rats given the 25C4M diet (Fig. 4). The gel filtration profile of the kidney water extract in the 10C $3 \mathrm{M}$ group was not different from that in the $25 \mathrm{C} 4 \mathrm{M}$ group. The accumulated amounts of LMM in the kidneys were 0.43 and $0.56 \mathrm{mg} / \mathrm{g}$ wet kidney in the $10 \mathrm{C} 3 \mathrm{M}$ and $25 \mathrm{C} 4 \mathrm{M}$ rats, respectively. The gel chromatographic pattern for the kidneys in the group given the LMM-supplemented diet in Exp. II showed that they contained a greater quantity of the LMM component than that in the case of the melanoidin-fed rats in Exp. I (Fig. 5). The quantity of the LMM component deposited in the kidneys of the LMM-diet fed group corresponded to $1.01 \mathrm{mg} / \mathrm{g}$ wet kidney.

Comparison of the gel filtration chromatography patterns on Sephadex G-75 in Exp. II (Figs. 1 and 6) showed that the melanoidin in the feces of the $25 \mathrm{C} 4 \mathrm{M}$ diet-supplied rats contained a larger amount of the LMM component. This result was different from that obtained in the work of Fujimaki et al. ${ }^{4,8)}$ There was no difference in the gel filtration patterns of water extracts of feces from the $10 \mathrm{C} 3 \mathrm{M}$ and $25 \mathrm{C} 4 \mathrm{M}$ groups. The ratio (mean $\pm \mathrm{SE}$ ) of excreted to ingested melanoidin determined colorimetrically on the basis of the optical density was $82.6 \pm 5.6 \%$ in the $10 \mathrm{C} 3 \mathrm{M}$ rats and $83.2 \pm 5.1 \%$ in the $25 \mathrm{C} 4 \mathrm{M}$ ones. The fecal gel chromatographic profile for 
Table III. Body Weight Gains, Food Intakes, Liver and Kidney Weights, Total Cholesterol and Total Lipids in the Plasma, Liver and Feces, and Protein, Creatine and Creatinine in the Urine of Rats Fed the Test Diets for 8 Weeks (Exp. II)

\begin{tabular}{|c|c|c|c|}
\hline \multirow[b]{2}{*}{ Analyzed item } & \multicolumn{3}{|c|}{ Dietary group } \\
\hline & \multirow{2}{*}{$\begin{array}{l}\begin{array}{l}25 \% \text { Casein } \\
(25 \mathrm{C})\end{array} \\
219.3 \pm 5.2^{b}\end{array}$} & \multirow{2}{*}{$\begin{array}{c}25 \mathrm{C}+3 \% \\
\text { melanoidin }(\mathrm{m})^{a} \\
216.0 \pm 7.0\end{array}$} & \multirow{2}{*}{$\begin{array}{c}25 \mathrm{C}+3 \% \\
\text { melanoidin }(\mathrm{M})^{a} \\
234.6+6.9\end{array}$} \\
\hline Body weight gain $\mathrm{g} / 8$ weeks & & & \\
\hline Food intake $\mathrm{g} / 8$ weeks & $771.9 \pm 17.2$ & $764.9 \pm 17.9$ & $796.5 \pm 16.6$ \\
\hline Liver weight $\mathrm{g} / 100 \mathrm{~g}$ body wt. & $4.16 \pm 0.10$ & $4.30 \pm 0.17$ & $4.29 \pm 0.16$ \\
\hline Kidney weight $\mathrm{g} / 100 \mathrm{~g}$ body wt. & $0.96 \pm 0.03$ & $1.08 \pm 0.09$ & $0.92 \pm 0.04$ \\
\hline plasma $\mathrm{mg} / 100 \mathrm{ml}$ & $92.2 \pm 3.4$ & $79.1 \pm 4.0^{*}$ & $82.3 \pm 2.9^{*}$ \\
\hline cholesterol liver $\mathrm{mg} / \mathrm{g}$ dry & $10.8 \pm 0.2$ & $11.2 \pm 0.3$ & $10.2 \pm 0.1$ \\
\hline $\begin{array}{ll}\text { feces } & \mathrm{mg} / 100 \mathrm{~g} \\
& \text { body wt./day }\end{array}$ & $0.9 \pm 0.5$ & $1.6 \pm 0.3$ & $1.6 \pm 0.3$ \\
\hline $\begin{array}{lll}\text { Total lipids }^{c} & \text { liver } & \begin{array}{l}\text { mg palmitic } \\
\text { acid/g dry }\end{array}\end{array}$ & $173.7 \pm 3.3$ & $174.9 \pm 8.2$ & $175.3 \pm 3.1$ \\
\hline $\begin{array}{ll}\text { feces } & \text { mg palmitic } \\
& \text { acid } / 100 \mathrm{~g} \text { body } \\
& \text { wt./day }\end{array}$ & $37.7 \pm 2.3$ & $60.8 \pm 3.7^{*}$ & $46.2 \pm 0.8^{*}$ \\
\hline plasma $\mathrm{mg} / 100 \mathrm{ml}$ & $3.25 \pm 0.14$ & $3.12 \pm 0.15$ & $2.76 \pm 0.20$ \\
\hline $\begin{array}{ll}\text { creatinine } & \text { urine } \\
& \begin{array}{l}\mathrm{mg} / 100 \mathrm{~g} \\
\text { body wt./day }\end{array}\end{array}$ & $1.23 \pm 0.13$ & $1.31 \pm 0.12$ & $1.33 \pm 0.08$ \\
\hline $\begin{array}{l}\mathrm{mg} / 100 \mathrm{~g} \\
\text { body wt./day }\end{array}$ & $3.21 \pm 0.33$ & $3.64 \pm 0.77$ & $3.85 \pm 0.88$ \\
\hline
\end{tabular}

a Low-molecular weight melanoidin component $(\mathrm{m})$ and a mixture of the low- and high-molecular weight component $(\mathrm{M})$.

${ }^{b}$ Mean \pm SE. * Significantly different from that in the $25 \mathrm{C}$ group at $p<0.05$, with the Student $t$-test.

$c$ Total lipids are expressed as the amount of palmitic acid.

rats fed the LMM diet in Exp. II showed a significantly increased quantity of the highmolecular weight component (Fig. 7).

\section{DISCUSSION}

Nondialyzable melanoidin did not affect the growth of rats, as reported previously, ${ }^{4,8,20)}$ but caused the formation of soft feces and was considered to keep the bowels active. Excess melanoidin, however, resulted in diarrhea.

A small amount of the low-molecular weight component (LMM) was deposited in the kidneys of the melanoidin- or LMM-fed rats (Figs. 3, 4 and 5). As protein has been found to be absorbed from the intestine, ${ }^{21,22)}$ though the rate of its absorption is at the most $2 \%,{ }^{22}$ ) melanoidin, an electrolyte like protein, especially the LMM component, can be absorbed as in the case of protein. The accumulation of melanoidin could be the result of the re- ciprocal action ${ }^{12)}$ between the kidney protein and absorbed LMM, since it was reported that the static electric bond between the melanoidin and protein was formed at the first step in the interaction between the two compounds. ${ }^{20)}$ The melanoidin accumulated in the kidney, and the approximately $80 \%$ fecal excretion of the ingested melanoidin, as described above, might suggest that an extremely small part of the absorbed melanoidin was deposited in the kidneys, and the residual melanoidin being excreted in the urine, though urinary melanoidin was not determined in the present experiments, and Fujimaki et al. ${ }^{8}{ }^{8}$ reported that brownish pigments were not found in the urine of melanoidin-fed rats.

Gel filtration of a water extract of the feces on Sephadex G-75 showed that the ingested melanoidin or LMM was almost all excreted in the feces, which was in agreement with the other reports. ${ }^{4,6,8)}$ Not all of the melanoidin 

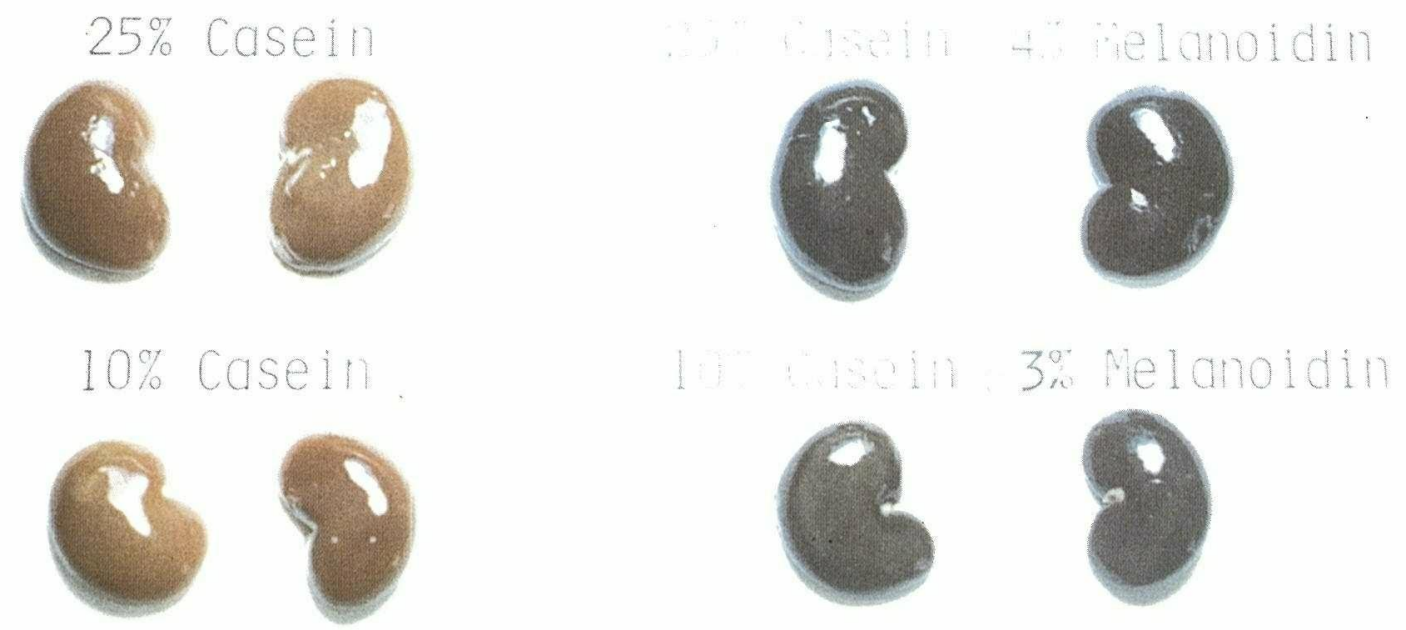

FIG. 3. Photograph of Kidneys from Rats Fed the 10\% Casein Diet Containing 3\% Melanoidin (10C3M) and the $4 \%$ Melanoidin-supplemented $25 \%$ Casein Diet (25C4M) for 12 Weeks (Exp. I).

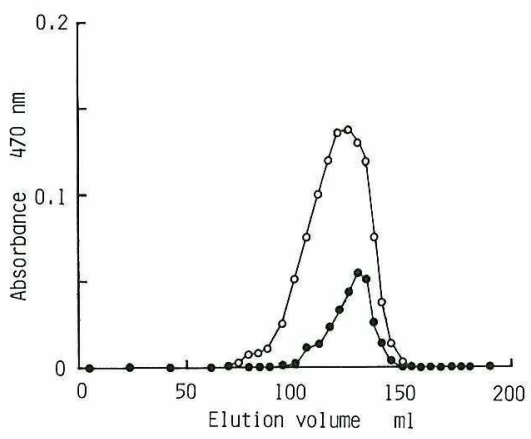

FIG. 4. Gel Filtration Chromatography of a Water Extract of the Kidneys of Rats Fed the $25 \%$ Casein (25C) Diet Containing $4 \%$ Melanoidin (25C4M) for 12 Weeks on Sephadex G-75 $(1.5 \times 78 \mathrm{~cm})($ Exp. I).

After rats had been fed the test diets for 12 weeks, they were killed and then their kidneys were removed. The kidneys were homogenized in distilled water, followed by deproteinization by the addition of sulfosalicylic acid and centrifugation at $12,000 \mathrm{rpm}$ for $20 \mathrm{~min}$, and then the supernatants were applied to a column of Sephadex G-75. The treatment of rats and other analytical conditions were as described in the text. $-\mathrm{O}-, 25 \mathrm{C} 4 \mathrm{M} ;-\mathrm{O}-25 \mathrm{C}$.

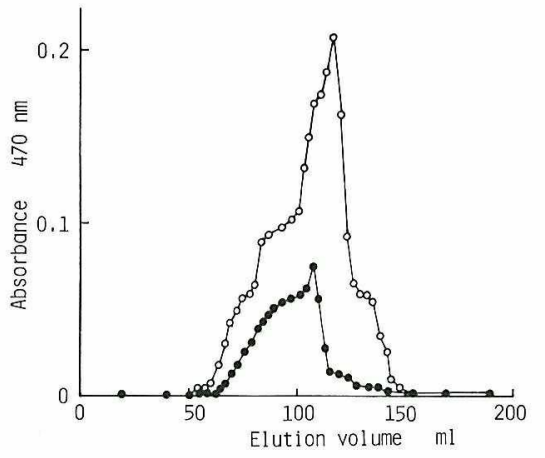

FIG. 5. Gel Filtration Chromatography of a Water Extract of the Kidneys of Rats Fed the $25 \%$ Casein (25C) Diet Containing 3\% Low-molecular Weight Melanoidin $(25 \mathrm{C} 3 \mathrm{~m})$ for 8 Weeks on Sephadex G-75 $(1.5 \times 78 \mathrm{~cm})$ (Exp. II).

The treatment of rats and the preparation of samples were as described in Fig. 4 and the text. $-\mathrm{O}-, 25 \mathrm{C} 3 \mathrm{~m}$; - - $25 \mathrm{C}$.

consumed by the rats, however, was recovered in the feces, as colorimetrically determined, as found in earlier works. ${ }^{8,23,24)}$ This could be 


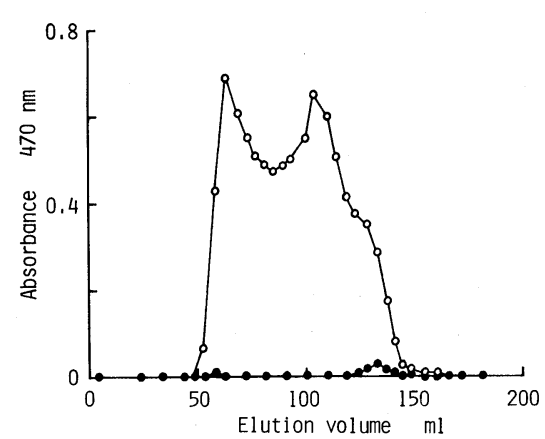

FIG. 6. Gel Filtration Chromatography of a Water Extract of the Feces of Rats Fed the 25\% Casein (25C) Diet Containing 4\% Melanoidin (25C4M) for 12 Weeks on Sephadex G-75 $(1.5 \times 78 \mathrm{~cm})($ Exp. I).

The feces were collected for the last 3 days before killing rats given the test diets for 12 weeks, dissolved in distilled water and then centrifuged at $2,500 \mathrm{rpm}$ for $20 \mathrm{~min}$. The supernatants were subjected to column chromatography on Sephadex G-75. $-\mathrm{O}-, 25 \mathrm{C} 3 \mathrm{~m} ;-\mathrm{O}-25 \mathrm{C}$.

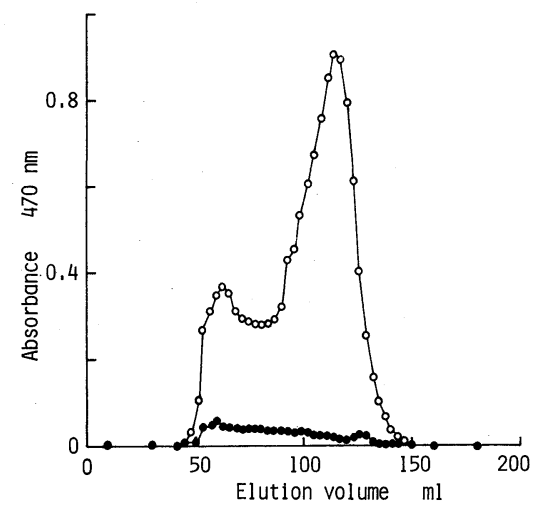

FIG. 7. Gel Filtration Chromatography of a Water Extract of the Feces of Rats Fed the 25\% Casein (25C) Diet Containing 3\% Low-molecular Weight Melanoidin $(25 \mathrm{C} 3 \mathrm{~m})$ for 8 Weeks on Sephadex G-75 $(1.5 \times 78 \mathrm{~cm})$ (Exp. II).

The treatment of rats and the preparation of samples were as described in Fig. 4 and the text. $-\mathrm{O}-, 25 \mathrm{C} 3 \mathrm{~m}$; $-\mathrm{O}-25 \mathrm{C}$.

partially due to alteration of the ingested melanoidin into less or none-colored compounds during the digestive process, ${ }^{8,23,24)}$ since the accumulated amount of melanoidin in the kidneys was extremely low in comparison with the amount ingested in the present experiments. The slightly increased proportion of the lower-molecular weight melanoidin in the feces of the melanoidin group in comparison with that in the control one (Fig. 6) might represent a degradation product, produced by the intestinal microflora, as described by Fujimaki et al. ${ }^{8)}$ When rats were given the LMM-supplemented diet, the amount of the high-molecular weight melanoidin component (HMM) was considerably increased in the excreted feces (Fig. 7). The increased fecal excretion of HMM would be due to the formation of melanoidin gel under the low $\mathrm{pH}$ in the stomach and the effect of microorganisms in the intestine, because Gomyo and Miura ${ }^{20)}$ reported that after rats had been force-fed a melanoidin solution, hard gelatinization of melanoidin occurred depending on the $\mathrm{pH}$ in the stomach, and then it became soft in the duodenum, and an elevated level of lactic acid and a decrease in $\mathrm{pH}$ in comparison with those in the control animals were observed.

In the present study, in which rats were given diets containing no cholesterol, the supplementation of melanoidin resulted in a decreased concentration of plasma cholesterol and did not change the content in the liver, and it increased the amounts of total lipids and total cholesterol excreted in the feces (Tables II and III). The results of other research $^{20)}$ demonstrated that melanoidin significantly suppressed the increase in plasma cholesterol level when supplemented to a highcholesterol diet. This effect was similar to the suppressive one of dietary fiber toward the increased cholesterol content in the plasma of cholesterol-provided rats, as reported previously. ${ }^{25,26)}$ These observations indicate that melanoidin has a specific effect on the absorption of lipids and cholesterol in the intestine.

The quantities of urinary excreted protein and total creatinine remained unchanged on feeding of the melanoidin diets, which may suggest that even if melanoidin is deposited in the kidneys, the ingested melanoidin hardly affects its function.

\section{REFERENCES}

1) G. C. Fahey, J. E. Williams and G. A. McLaren, J. 
Nutr., 106, 1447 (1976).

2) C. M. Lee, C. O. Chichester and T-C. Lee, "Physiological Consequences of Browned Food Products," Proc. Int. Cong. Food Sci. Technol., 4th, 1977.

3) K. Olssen, P. A. Pernemalm and O. Theander, Prog. Food Nutr. Sci., 5, 47 (1981).

4) S. Homma and M. Fujimaki, Prog. Food Nutr. Sci., 5, 209 (1981).

5) J. Valle-Riestra and R. H. Barnes, J. Nutr., 100, 873 (1970).

6) R. Öste, I. Björk, A. Dahlquvist, M. Jägestad, P. Sjödin and H. Sjöström, Am. Chem. Soc., Symp. Ser., 215, 405 (1983).

7) R. Öste and P. Sjödin, J. Nutr., 114, 2228 (1984).

8) M. Fujimaki, S. Homma, N. Arakawa and C. Inagaki, Agric. Biol. Chem., 43, 497 (1979).

9) T-C. Lee, M. Kimigar, S. J. Pintauro and C. O. Chichester, Prog. Food Nutr. Sci., 5, 243 (1981).

10) H. Kato, T. Gomyo, K. Udaka and M. Fujimaki, Nippon Nōgeikagaku Kaishi, 45, 559 (1971).

11) T. Gomyo and M. Horikoshi, Agric. Biol. Chem., 40, 33 (1976).

12) M. Horikoshi and T. Gomyo, Agric. Biol Chem., 40, 1531 (1976).

13) N. Okada, T. Ohta and H. Ebine, Nippon Nōgeikagaku Kaishi, 56, 93 (1982).
14) M. Kitamura, "Clinical Chemical Analysis," Vol. III, ed. by M. Niwa, M. Kitamura and M. Saito, Tokyo Kagakudōzin, Tokyo, 1968, p. 72.

15) J. Folch, M. Lees and G. H. Sloane-Stanley, J. Biol. Chem., 226, 497 (1957).

16) J. H. Bragdon, J. Biol. Chem., 190, 153 (1951).

17) E. C. H. Van Beresteyn, M. Van Schaik and M. F. Kerkhof Mogot, J. Nutr., 109, 2085 (1979).

18) H. Takeuchi, T. Tanaka and K. Muramatsu, Agric. Biol. Chem., 33, 1161 (1969).

19) E. Layne, "Methods in Enzymology," Vol. III, ed. by S. P. Colowick and N. O. Kaplan, Academic Press Inc., New York, 1957, p. 447.

20) T. Gomyo and M. Miura, Nippon Eiyō Syokuryō Gakkaishi, 36, 331 (1983).

21) K. Katayama and T. Fujita, Biochim. Biophys. Acta, 288, 181 (1972).

22) A. L. Warshaw, W. A. Walker and K. J. Isselbacher, Gastroenterol., 66, 987 (1974).

23) M. C. Nesheim and K. J. Carpenter, Brit. J. Nutr., 21, 399 (1966).

24) M. Tanaka, T-C. Lee and C. O. Chichester, J. Nutr., 105, 989 (1975).

25) K. Kiriyama, Kagaku to Seibutsu, 18, 95 (1980).

26) K. Tsuji, "Dietary Fiber," ed. by T. Innami and S. Kiriyama, Daiichishuppan, Tokyo, 1982, p. 131. 